\title{
What Agglomeration Externalities Impact the Development of the Hi-tech Industry Sector? Evidence from the Russian Regions
}

\author{
Angi Skhvediani ${ }^{*}$, Sergey Sosnovskikh ${ }^{2}$
}

${ }^{1}$ Graduate School of Industrial Economics, Institute of Industrial Management, Economics and Trade, Peter the Great St. Petersburg Polytechnic University, Polytechnicheskaya 29, Saint Petersburg, 195251, Russian Federation

${ }^{2}$ Department of Management and Entrepreneurship, Leicester Castle Business School, De Montfort University, The Gateway, Leicester, United Kingdom, LE1 9BH, UK

\begin{abstract}
This paper continues the ongoing debate on the importance of agglomeration externalities that may impact innovation development and the high-technology sector in regional economies. Previous studies suggest that the evidence for agglomeration externalities is strongly context-specific. We aimed to expand this discussion to Russian regions by utilising statistical evidence. We constructed a panel dataset with 83 regions and used various spatial econometrics and statistic techniques to test our hypothesis. Our study made two essential contributions. First, we found that regions with a high density of used high technologies tended to co-locate next to each other. Secondly, the localization of employment, sales volume, and paid wages in the electrical equipment, electronic, and optical equipment sector demonstrated a positive association with hitech usage density. These externalities suggest the presence of positive direct or indirect spillover effects among regions in Russia within the examined industry sector. However, the localization of investment did not display any association and, thus, does not suggest the presence of any spillover effects. These contrasting findings reveal the peculiarities of Russian business reality, such as vast territories of the country, uneven infrastructure, lack of funding, and small cooperate networks. The federal government is expected to provide appropriate financial and legal support to stimulate clustering processes and innovative activities. Recommendation for further research is provided at the end of the paper.
\end{abstract}

Keywords: Agglomeration; Innovation; Localization; Russia; Spillovers

\section{Introduction}

After the collapse of the Soviet Union in 1991, the newly formed Russian Federation went through a prolonged financial and economic crisis, the consequences of which are being felt well into the 2010s. During this time, industrial sectors that were traditionally dependent on state funding, such as the military sector, research and development (R\&D) and social services, saw state contributions significantly reduced (Oglobina et al., 2002). As a result, $R \& D$ investment fell dramatically, and a significant downsizing of the Russian $R \& D$ system occurred. Russian enterprises and multinational corporations gave preference to imported products instead of innovating their own. This was due to the low costs of imported goods and quick financial returns, whereas R\&D investment involved a high level

${ }^{*}$ Corresponding author's email: shvediani_ae@spbstu.ru, Tel.: +7-812-534-73-31 doi: 10.14716/ijtech.v11i6.4423 
of uncertainty. Business innovation in Russia became weak (Klochikhin, 2012; Kudryavtseva et al., 2020).

Furthermore, the innovation activity of Russian companies remains considerably uneven across regions, which is due to a lack of funding, state support, and dominating industrial sectors (Rodionov and Velichenkova, 2020; Moskovkin et al., 2016). According to Kuznetsova and Roud (2014), most Russian companies across different industries do not give high priority to increasing the innovativeness of their products. Only a small number of firms are active on the market and regularly update their product lines by introducing innovations. This could be due to how companies structure various types of innovation efforts, outdated models of development strategies, and ineffective internal management (Bessonova and Gonchar, 2017). Given the close link between the integration of technologies and innovation, long-term sustained growth and an increase in general productivity may be under threat. The policymakers in Russia attempted to transform the R\&D sector, mainly through new legislation and tax incentives (Rodionova et al., 2018)

In this study, we intend to examine the electrical equipment, electronic, and optical equipment sector in Russia, which is typically labeled as the "hi-tech" sector and involves technological development and innovations by the Russian Federal State Statistics Service («Poccmam»). The federal government has given the hi-tech industry significant attention in Russia in its attempts to stimulate innovative development in the country (Crescenzi and Jaax, 2017; Samsonov et al., 2017). The general research question is as follows: Does the existence of the companies operating in the hi-tech industry sector in one region generate the use of hi-tech products by companies located in other regions? More specifically, the goal of this study is to investigate what agglomeration externalities impact the development of the hi-tech sector in the Russian regions.

Our paper is structured as follows. The next chapter provides a theoretical discussion regarding the concept of clustering, agglomeration economies, spillover effects, and how these are important for innovation development. Then, data collection and analysis methods are described. The fourth section presents and discusses the test results. Finally, the paper analyzes the findings in light of the existing theoretical debate. It concludes with a reflection on the implications for future development of the hi-tech sector across the Russian regions and recommendations for further research.

\section{Literature Review}

The concept of agglomeration economies and industrial clusters have been discussed since the beginning of the 20th century by several scholars. Marshall (2013) was one of the first who suggested the term "Industrial Districts" to characterize the benefits gained by locating firms in the same geographical area. He identified the benefits of the districts, stating that geographic agglomerations could eventually lead to three types of externalities: a) specialized workers; b) specialized suppliers of inputs and services; and c) technological and knowledge spillovers among co-located companies. Marshall's knowledge spillovers were extended by Arrow (1962) and Romer (1986). In 1992, their views were combined and labeled as Marshall-Arrow-Romer (MAR) knowledge spillovers (Iammarino and McCann, 2006). It meant that the proximity of firms within a similar industry often affects how knowledge travels among firms to facilitate innovation and growth. Porter (1990) defines industrial clusters as a geographically proximate group of interconnected companies and associated institutions in a particular field. He emphasizes the significance of local rivalry and supplier networks within the cluster, as well as the combination of geographical specifics and government policies that lead to productivity growth. Porter also suggests the importance of other components for creating competitive advantages, such as 
universities, infrastructure, service providers, suppliers of specialized inputs, and trade associations. Krugman (1991) suggests that the fundamental idea of agglomeration economies is not the mere provision of goods and services, but also includes, more importantly, knowledge creation and innovation. Becattini et al. (2003) extends the clustering concept of the purely economic effects of agglomeration to a broader scope, involving the social, cultural, and institutional foundations of local industrial growth. He suggests the idea of the "embeddedness" of the local industrial structure, which is fostered by proximity. Agglomeration effects operate when firms from different industries are related to each other in terms of the production of goods and services valued by customers. When some of these positive externalities occur naturally, their dynamic can be stimulated through a combination of networking, collaboration, and competition.

Numerous contemporary studies suggest that industry location increases factor productivity: being part of a cluster enables companies to productively source inputs and access information, technology, and institutions, and it also allows them to cooperate with other firms both horizontally and vertically (Feldman et al., 2005; Carpinetti and Lima, 2013; Delgado et al., 2016). Local accumulation of companies that are typically specialized in one product, a part of a product, or a phase of production detains together, by interpersonal relationships, a common social culture of workers, entrepreneurs, and policymakers surrounded by an industrial environment that accelerates the dissemination of innovation, generating significant flows of external economies that remain internal to the local productive system (Ronen and Shenkar, 2013; Nestle et al., 2019). If the cluster progresses successfully further, positive externalities start to arise in the form of attracting new firms, the emergence of start-ups, increased internal investment flows, and the inflow of human capital (Putri et al. 2016). Besides the unexpected profits of external economies, firms may increase their competitive advantage with the help of joint actions, which are the result of tight cooperation and collaboration among members (Wiratmadja et al., 2016; Kudryavtseva and Olaniyi, 2019). The coexistence of competition and cooperation is a significant feature of agglomeration economies. Cooperation within clusters enables firms to gain advantages from the mutual exchange of information and to specialize in alignment of their capabilities. Moreover, competition reinforces the need to innovate constantly at the firm level to maintain individual firms' position in the value chain (Newlands, 2003; Ketels, 2013). Co-location raises the awareness of emerging tendencies and decreases uncertainty for firms: Innovation clusters spatially in locations where knowledge externalities reduce the costs of discovery and commercialization (Enkel et al., 2009; Xie et al., 2016). The dynamic between different forms and quality of networks and resources, as well as institutions, promotes business interests and has a fundamental impact on the sustainability of start-ups (Berawi, 2016). Hence, the cluster is an agglomeration of jointly reinforcing firms and aligned interests.

Policymakers should give preference to strengthen or build on established or emerging agglomeration economies (brownfields) than strive to make entirely new ones (Bychkova and Rudskaia, 2018). The procedure of cluster improvement implies an acknowledgement of necessity in generating a number of initiatives, such as removing obstacles and lessening limitations (i.e., human resource infrastructure and regulatory constraints) and eliminating inefficiencies that delay productivity and innovation in the region (Vernay et al., 2018). Governments often strive to improve the competitiveness of individual companies by providing them with various subsidies and technology grants (Aggarwal, 2011). Despite the fact that the majority of clusters can offer the potential for successful development and prosperity, the main question is not what the nation or location is willing to compete in but how it is going to do so (Moeis et al., 2020). Cluster thinking comprehends the importance 
of initiatives at the national and regional levels. Thus, governments have to accept the aspiration of competitive advantage and specialization (Delgado et al., 2014). Table 1 provides a summary of previous studies that have evaluated the effects of agglomeration externalities on the economic performance of various regions.

Table 1 The summary of previous studies evaluating the effects of agglomeration externalities on the economic performance of the regions

\begin{tabular}{llccc}
\hline \multirow{2}{*}{ Type of impact } & \multicolumn{1}{c}{$\begin{array}{c}\text { Unit of } \\
\text { measurements }\end{array}$} & $\begin{array}{c}\text { Concentration of } \\
\text { economic activity }\end{array}$ & $\begin{array}{c}\text { Diversification of } \\
\text { economic activity }\end{array}$ & Competition \\
\hline \multirow{2}{*}{ Negative } & Number of studies & 119 & 46 & 35 \\
& Proportion, \% & 36.2 & 14.8 & 19.8 \\
\hline \multirow{2}{*}{ Insignificant } & Number of studies & 90 & 143 & 45 \\
& Proportion, \% & 27.4 & 46 & 25.4 \\
\hline \multirow{2}{*}{ Positive } & Number of studies & 120 & 122 & 97 \\
\hline Total & Proportion, \% & 36.4 & 39.2 & 54.8 \\
\hline
\end{tabular}

Source: de Groot et al. (2016)

In the wake of the new Russian economy that developed after the collapse of the USSR, new types of connections among companies emerged. This new breed of companies has survived in conditions of fierce competition with new foreign rivals (Sakwa, 2008). Their typical history includes disintegration of technological networks of the Soviet system for imports in the first half of the 1990s; the establishment of the production of competitive goods after the financial crisis of 1998; and new problems associated with the evolution of a mature market, such as the establishment of branches of transnational corporations, the introduction of cheap Chinese imports, and general pressure from new Russian firms (Kets de Vries et al., 2004). The new firms survived in such conditions because they learned to respond to the competitive advantages of rivals by creating their own strengths, and the hitech sector was one of them. The beginning of the transition economy witnessed a collapse of these "allocated" relationships between former suppliers and producers. This collapse caused supply problems within industries, particularly in those where suppliers were located in the former Soviet republics (Burawoy, 2001). Hence, in this study, the case of Russia raises a specific interest for investigation because there is high concern regarding competition and innovative development. The product markets are substantially separated geographically due to their massive size and uneven infrastructure and transportation links (Brown and Earle, 2000; Tsukhlo, 2007). We intend to investigate whether government initiatives have had any impact on the development of the hi-tech sector across Russian regions by examining specific factors.

\section{Methods}

\subsection{Data}

We collected initial data from the Russian Federal State Statistics Service («Poccmam») and made calculations to obtain necessary estimates. Except for $I_{i g t}^{L Q}$, all the data were collected for 83 Russian regions for the period of 2009-2018. Since there were no available data on investments by industry before $2012, I_{\text {igt }}^{L Q}$ was calculated only for the period 20132018. As a dependent variable, we took a number of hi-tech technologies used in the region 
per person employed. According to the Russian Federal State Statistics Service, hi-tech technologies include automated transportation systems, complete products control, wireless telecommunication systems, integrated management and control systems, artificial intelligence technologies, flexible manufacturing cells, and so on. Therefore, this dependent variable was used to represent the density of the digital technologies used in the specific region. Table 2 provides the summary of the dependent, independent, and control variables.

We used locational quotient (LQ) to calculate five independent variables that show the relative concentration of the different electrical equipment, electronic, and optical equipment industry parameters. We extended the usual list of parameters that are used for calculation of the LQ and included such parameters as sales, investments, and wages. Furthermore, we used some control variables to control differences in the density of used hi-tech technologies, which could not be explained by localization of electrical equipment, electronic, and optical equipment industries.

Table 2 Variables and their definitions

\begin{tabular}{|c|c|c|}
\hline Variable name & $\begin{array}{l}\text { Variable } \\
\text { type }\end{array}$ & Definitions \\
\hline hitechdens $s_{g t}$ & $\begin{array}{l}\text { Dependent } \\
\text { variable }\end{array}$ & $\begin{array}{l}\text { Quantity of innovative industrial technologies used per one } \\
\text { employed in the region } g \text { per year } t \text {, persons }\end{array}$ \\
\hline$E_{i g t}^{L Q}=\frac{E_{i g t}}{E_{g t}} / \frac{E_{i t}}{E_{t}}$ & \multirow{4}{*}{$\begin{array}{l}\text { Independent } \\
\text { variables }\end{array}$} & $\begin{array}{l}\text { Coefficient of localization (relative concentration) of the number of } \\
\text { employed in industry } i \text { in region } g \text { in year } t\end{array}$ \\
\hline$S_{i g t}^{L Q}=\frac{S_{i g t}}{S_{g t}} / \frac{S_{i t}}{S_{t}}$ & & $\begin{array}{l}\text { Coefficient of localization (relative concentration) of the volume of } \\
\text { sales revenues in industry } i \text { in region } g \text { in year } t\end{array}$ \\
\hline$I_{i g t}^{L Q}=\frac{I_{i g t}}{I_{g t}} / \frac{I_{i t}}{I_{t}}$ & & $\begin{array}{l}\text { Coefficient of localization (relative concentration) of the volume of } \\
\text { investments in industry } i \text { in region } g \text { in year } t\end{array}$ \\
\hline$W_{i g t}^{L Q}=\frac{W_{i g t}}{W_{g t}} / \frac{W_{i t}}{W_{t}}$ & & $\begin{array}{l}\text { Coefficient of localization (relative concentration) of wages in } \\
\text { industry } i \text { in region } g \text { in year } t\end{array}$ \\
\hline$c r_{g t}$ & \multirow{6}{*}{$\begin{array}{l}\text { Control } \\
\text { variables } \\
\qquad\left(\boldsymbol{X}_{t}\right)\end{array}$} & Number of crimes in region $g$ in year $t$, units \\
\hline $\operatorname{lexp} p_{g t}$ & & Life expectancy in region $g$ in year $t$, years \\
\hline unem $_{g t}$ & & Share of unemployed in region $g$ in year $t, \%$ \\
\hline chim $_{g t}$ & & Infant mortality in region $g$ in year $t$, deaths per 1,000 births \\
\hline resdens $_{g t}$ & & $\begin{array}{l}\text { Number of researchers per one employed in region } g \text { in year } t \text {, } \\
\text { persons }\end{array}$ \\
\hline preschool $_{g t}$ & & $\begin{array}{l}\text { Gross preschool enrolment ratio, as a percentage of the number of } \\
\text { children aged between } 1 \text { and } 6 \text { years }\end{array}$ \\
\hline
\end{tabular}

\subsection{Methodology}

In this study, we used spatial econometrics and statistical techniques to identify the type of externalities and to assess the spillover effects from localization of the electrical equipment, electronic, and optical equipment industry in the regions (Kudryavtseva et al., 2020). We analyzed the pattern of the electrical equipment, electronic, and optical equipment industry localization using Global Moran's index and Moran's scatterplot. Global Moran's index enables the analysis of spatial autocorrelation of the regions by a chosen parameter. This metric shows whether there is any significant tendency among the regions either to cluster by similar or dissimilar values. Moran's index of spatial autocorrelation is computed as follows:

$$
I=\frac{n}{\sum_{k=1}^{n}\left(y_{k}-\bar{y}\right)^{2}} \frac{\sum_{k=1}^{n} \sum_{m=1}^{n} w_{k m}\left(y_{k}-\bar{y}\right)\left(y_{m}-\bar{y}\right)}{\sum_{k=1}^{n} \sum_{m=1}^{n} w_{k m}}
$$


where $y$ refers to the natural logarithm of hitechdens ${ }_{g t}$, and $w_{k m}$ - spatial weight matrix and $k, m$ - indexes refer to the neighboring regions.

The interpretation of Moran's index resembles the interpretation of the standard correlation measure. Moran's scatterplot allows visualization of this correlation. Next, we used a spatial econometric model to determine the relation between independent and dependent variables and to identify the externality type.

We used the Spatial Durbin Model (SDM) since it does not suffer from overparameterization as is the case with the general nesting spatial model (GNS) (Elhorst, 2014). Furthermore, we utilized the fixed and random effects models for estimation of Equations 2-5. Each equation contains only one independent variable to lower the effect of multicollinearity on the obtained estimates.

$$
\begin{aligned}
& \text { lnhitechdens }_{g t}=\delta \boldsymbol{W} \text { lnhitechdens } s_{g t}+\alpha \boldsymbol{i}_{\boldsymbol{N}}+\beta_{1} E_{i g t}^{L Q}+\boldsymbol{W} E_{i g t}^{L Q} \theta_{1}+\gamma_{k} \boldsymbol{X}_{t}+\boldsymbol{\varepsilon}_{\boldsymbol{t}} \\
& \text { lnhitechdens }_{g t}=\delta \boldsymbol{W} \text { lnhitechdens }{ }_{g t}+\alpha \boldsymbol{i}_{N}+\beta_{2} S_{i g t}^{L Q}+\boldsymbol{W} S_{i g t}^{L Q} \theta_{2}+\gamma_{k} \boldsymbol{X}_{t}+\boldsymbol{\varepsilon}_{\boldsymbol{t}} \\
& \text { lnhitechdens }_{g t}=\delta \boldsymbol{W} \text { lnhitechdens }{ }_{g t}+\alpha \boldsymbol{i}_{N}+\beta_{3} I_{i g t}^{L Q}+\boldsymbol{W} I_{i g t}^{L Q} \theta_{3}+\gamma_{k} \boldsymbol{X}_{t}+\boldsymbol{\varepsilon}_{\boldsymbol{t}} \\
& \text { lnhitechdens }_{g t}=\delta \boldsymbol{W} \text { lnhitechdens }_{g t}+\alpha \boldsymbol{i}_{N}+\beta_{4} W_{i g t}^{L Q}+\boldsymbol{W} W_{i g t}^{L Q} \theta_{4}+\gamma_{k} \boldsymbol{X}_{t}+\boldsymbol{\varepsilon}_{\boldsymbol{t}}
\end{aligned}
$$

Index $g$ refers to the Russian region; index $t$ refers to the year; index $i$ refers to the industry; $g t$ refers to the region-level data; and igt refers to the industry level data of the region. Variables lnhitechdens $_{g t}, \boldsymbol{X}_{t}$ are defined in Table 2. Furthermore, $\delta, \alpha, \beta_{1}-\beta_{4}, \gamma_{k}$ are model parameters; $\boldsymbol{W}$ is the inverse distance spatial weight matrix; $\boldsymbol{i}_{\boldsymbol{N}}$ is the vector of ones; and $\boldsymbol{\varepsilon}_{\boldsymbol{t}}$ is the vector of disturbance term.

\section{Results and Discussion}

\subsection{Analysis of Dependent Variable Spatial Autocorrelation}

We analyzed the spatial autocorrelation of the dependent variable: the natural logarithm of hi-tech technologies used in the region per person employed. Moran's I statistics show the presence of the positive autocorrelation (see Table 3), which means that regions cluster by similar values of the dependent variables. Therefore, regions with a high density of the used high technologies tend to collocate next to each other.

Table 3 Moran's I statistics

\begin{tabular}{ccccccccccc}
\hline & 2009 & 2010 & 2011 & 2012 & 2013 & 2014 & 2015 & 2016 & 2017 & 2018 \\
\hline Moran's I & 0.106 & 0.111 & 0.129 & 0.111 & 0.098 & 0.108 & 0.124 & 0.099 & 0.07 & 0.07 \\
P-value & 0.001 & 0.001 & 0.001 & 0.001 & 0.003 & 0.002 & 0.002 & 0.001 & 0.002 & 0.002 \\
\hline
\end{tabular}

Figure 1 presents Moran's I scatterplot for the natural logarithm of hi-tech technologies used in the region per person employed. It demonstrates the scattering of the Russian regions by the spatially lagged value of the variable against its $z$ value. Therefore, the distribution of the dependent variable in 2009 was stricter in terms of correlation. Hence, more regions follow the tendency for high-high or low-low co-location. Moreover, in 2009, there were more outliers in terms of small values of the hi-tech technologies used in the region per person employed compared to 2018. This may imply a shift in the density of high-technology usage from clusters of regions with similar characteristics to either strong regions neighbored by weak regions or to weak regions neighbored by strong ones. In any case, in the long term, it may lead to an increase in the disproportionality of high-technology usage among Russian regions and their concentration in strong regional centers. 


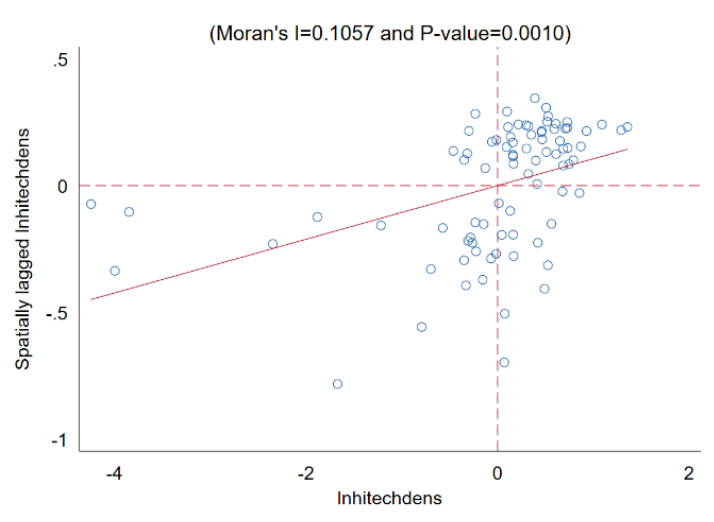

(a)

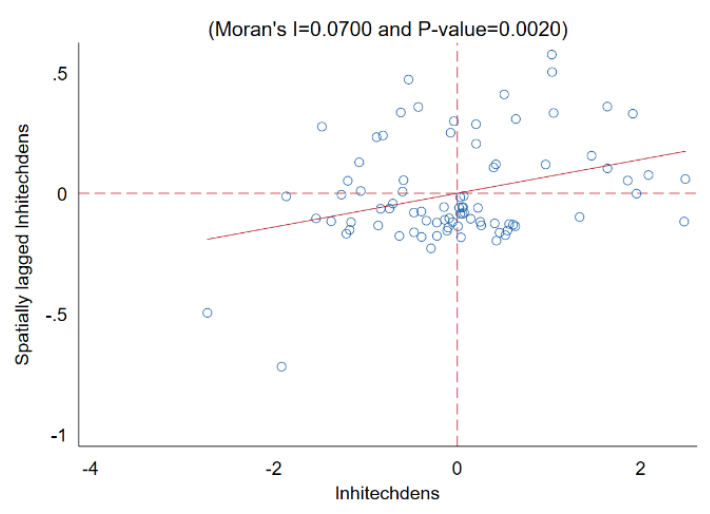

(b)

Figure 1 Moran's I for natural logarithm of hi-tech technologies used in the region per person employed in 2009 (a) and 2018 (b)

\subsection{Regression Modeling of the Industrial Regional Specialization}

Table 4 presents the results of the regression modeling for the independent variables $\mathrm{E}_{\text {igt }}^{\mathrm{LQ}}, \mathrm{S}_{\text {igt }}^{\mathrm{LQ}}, \mathrm{I}_{\text {igt }}^{\mathrm{LQ}}$, and $\mathrm{W}_{\text {igt }}^{\mathrm{LQ}}$. Each model is estimated with two variations: fixed and random effects. We used two types of models for each equation to test the stability of the estimated parameters and checked whether these estimates were still significant under various assumptions. The localization of people employed in the electrical equipment, electronic, and optical equipment industry is positively associated with the natural logarithm of hitech technologies usage density. This correlation is significant for both $E_{\text {igt }}^{\mathrm{LQ}}$ and spatially lagged $E_{\text {igt }}^{\mathrm{LQ}}$ at the 0.001 level. It implies positive agglomeration externalities from employment localization expressed in a higher density of the high technologies used in the regions. Therefore, such externalities suggest the presence of positive direct and indirect spillover effects among the regions within the studied industry sector.

The localization of sales volume in the studied industry is positively associated with the natural logarithm of hi-tech technologies usage density. This correlation is significant both for $S_{\text {igt }}^{\mathrm{LQ}}$ and spatially lagged $S_{\text {igt }}^{\mathrm{LQ}}$ at the 0.05 level for the fixed effects model and 0.01 for the random-effects model. Similar to the previous variable, it implies positive agglomeration externalities from sales localization expressed in a higher density of the high technologies used in the regions, which demonstrates the presence of direct and indirect spillover effects. However, the localization of investments volume is not associated with the natural logarithm of hi-tech technologies usage density. This relation is not significant for both $\mathrm{I}_{\text {igt }}^{\mathrm{LQ}}$ and spatially lagged $\mathrm{I}_{\mathrm{igt}}^{\mathrm{LQ}}$. This implies that localization of the investments does not produce any positive effects in the electrical equipment, electronic, and optical equipment industry. There can be three reasons for such an effect. First, this industry sector is essentially underfunded in Russian regions due to the current challenging economic situation in the country (Serebryakova et al., 2018; Lyapina et al., 2019). Secondly, although the government strives to stimulate the formation of clusters in Russia, companies struggle to cooperate and establish business networks, due to various institutional factors, such as cultural peculiarities (Sosnovskikh, 2017), business uncertainty (Grigoriev and Dekalchuk, 2017), and relationships with the government itself (Sharafutdinova and Steinbuks, 2017). Third, our tests revealed an absence of lag between investments (input) and results (density of the used high-technologies). The localization of wages in the examined industry sector is positively associated with the natural logarithm of the usage density of hi-tech 
technologies. This correlation is significant both for $\mathrm{W}_{\text {igt }}^{\mathrm{LQ}}$ and spatially lagged $\mathrm{W}_{\text {igt }}^{\mathrm{LQ}}$ in the random effects model. It suggests positive agglomeration externalities from employment localization expressed in higher density of the high technologies used in the regions and implies positive direct and indirect spillover effects.

Table 4 Results of the regression modeling: Equations 2-5

\begin{tabular}{|c|c|c|c|c|c|c|c|c|}
\hline $\begin{array}{l}\text { Model } \\
\text { parameters }\end{array}$ & 2.1 & 2.2 & 3.1 & 3.2 & 4.1 & 4.2 & 5.1 & 5.2 \\
\hline$E_{\text {igt }}^{\mathrm{LQ}}$ & $\begin{array}{c}1.546^{* * * *} \\
(0.311)\end{array}$ & $\begin{array}{c}0.529^{* * * *} \\
(0.158)\end{array}$ & & & & & & \\
\hline$S_{\text {igt }}^{L Q}$ & & & $\begin{array}{l}0.205^{* *} \\
(0.082)\end{array}$ & $\begin{array}{c}0.173^{* * *} \\
(0.055)\end{array}$ & & & & \\
\hline$I_{i g t}^{L Q}$ & & & & & $\begin{array}{l}-0.322 \\
(0.213)\end{array}$ & $\begin{array}{l}-0.045 \\
(0.128)\end{array}$ & & \\
\hline $\mathrm{W}_{\mathrm{igt}}^{\mathrm{LQ}}$ & & & & & & & $\begin{array}{c}0.934^{* * *} \\
(0.358)\end{array}$ & $\begin{array}{c}1.527^{* * * *} \\
(0.258)\end{array}$ \\
\hline $\operatorname{lnchim}_{\mathrm{gt}}$ & $\begin{array}{c}1.447^{* * * *} \\
(0.305)\end{array}$ & $\begin{array}{c}1.723^{* * * *} \\
(0.285)\end{array}$ & $\begin{array}{c}1.498^{* * * *} \\
(0.319)\end{array}$ & $\begin{array}{c}1.596^{* * * *} \\
(0.299)\end{array}$ & $\begin{array}{l}-0.633 \\
(0.537)\end{array}$ & $\begin{array}{c}1.802^{* * * *} \\
(0.383)\end{array}$ & $\begin{array}{c}1.546^{* * * *} \\
(0.320)\end{array}$ & $\begin{array}{c}1.269^{* * * *} \\
(0.262)\end{array}$ \\
\hline $\operatorname{lncr} g t$ & $\begin{array}{c}2.278^{* * * *} \\
(0.395)\end{array}$ & $\begin{array}{c}0.443^{* * * *} \\
(0.133)\end{array}$ & $\begin{array}{c}2.520^{* * * *} \\
(0.425)\end{array}$ & $\begin{array}{c}0.631^{* * * *} \\
(0.146)\end{array}$ & $\begin{array}{c}5.947^{* * * *} \\
(0.910)\end{array}$ & $\begin{array}{c}0.013 \\
(0.126)\end{array}$ & $\begin{array}{c}2.321^{* * * *} \\
(0.438)\end{array}$ & $\begin{array}{c}0.080 \\
(0.097)\end{array}$ \\
\hline $\operatorname{lnlexp} p_{\mathrm{gt}}$ & $\begin{array}{c}-33.363^{* * * *} \\
(4.255)\end{array}$ & $\begin{array}{l}-6.289^{* *} \\
(2.819)\end{array}$ & $\begin{array}{c}-29.597^{* * * *} \\
(4.371)\end{array}$ & $\begin{array}{c}-9.169^{* * *} \\
(3.007)\end{array}$ & $\begin{array}{c}-110.000^{* * * *} \\
(11.012)\end{array}$ & $\begin{array}{c}0.428 \\
(4.309) \\
\end{array}$ & $\begin{array}{c}-26.044^{* * * *} \\
(4.324)\end{array}$ & $\begin{array}{c}-5.652^{* *} \\
(2.253)\end{array}$ \\
\hline unem $_{\mathrm{gt}}$ & $\begin{array}{c}-0.099^{* * *} \\
(0.031)\end{array}$ & $\begin{array}{l}-0.038 \\
(0.025)\end{array}$ & $\begin{array}{c}-0.109^{* * * *} \\
(0.032)\end{array}$ & $\begin{array}{c}-0.059^{* *} \\
(0.026)\end{array}$ & $\begin{array}{c}0.040 \\
(0.082)\end{array}$ & $\begin{array}{l}-0.011 \\
(0.037)\end{array}$ & $\begin{array}{c}-0.098^{* * *} \\
(0.033)\end{array}$ & $\begin{array}{c}-0.048^{* *} \\
(0.021)\end{array}$ \\
\hline preschool $_{g t}$ & $\begin{array}{c}0.045^{* * *} \\
(0.017)\end{array}$ & $\begin{array}{c}-0.023^{* *} \\
(0.011)\end{array}$ & $\begin{array}{l}0.037^{* *} \\
(0.018)\end{array}$ & $\begin{array}{c}-0.026^{* *} \\
(0.011)\end{array}$ & $\begin{array}{c}0.114^{* * *} \\
(0.035)\end{array}$ & $\begin{array}{c}-0.013 \\
(0.014)\end{array}$ & $\begin{array}{c}0.034^{*} \\
(0.018)\end{array}$ & $\begin{array}{c}-0.006 \\
(0.009)\end{array}$ \\
\hline lnresdens $_{\mathrm{gt}}$ & $\begin{array}{c}0.063 \\
(0.209) \\
\end{array}$ & $\begin{array}{l}-0.120 \\
(0.116)\end{array}$ & $\begin{array}{c}0.056 \\
(0.216)\end{array}$ & $\begin{array}{c}-0.055 \\
(0.120)\end{array}$ & $\begin{array}{l}1.012^{* * *} \\
(0.336)\end{array}$ & $\begin{array}{c}0.042 \\
(0.110)\end{array}$ & $\begin{array}{c}0.150 \\
(0.219)\end{array}$ & $\begin{array}{c}-0.007 \\
(0.082)\end{array}$ \\
\hline$W E_{\text {igt }}^{L Q}$ & $\begin{array}{c}8.808^{* * * *} \\
(1.822)\end{array}$ & $\begin{array}{c}4.400^{* * * *} \\
(0.293)\end{array}$ & & & & & & \\
\hline$w S_{\text {igt }}^{L Q}$ & & & $\begin{array}{l}0.700^{* *} \\
(0.334)\end{array}$ & $\begin{array}{c}2.170^{* * * *} \\
(0.156)\end{array}$ & & & & \\
\hline$W \mathrm{I}_{\mathrm{igt}}^{\mathrm{LQ}}$ & & & & & $\begin{array}{c}-2.728 \\
(2.561)\end{array}$ & $\begin{array}{c}5.428^{* * * *} \\
(0.249)\end{array}$ & & \\
\hline $\boldsymbol{W} \mathrm{W}_{\mathrm{igt}}^{\mathrm{LQ}}$ & & & & & & & $\begin{array}{l}-2.286 \\
(2.495)\end{array}$ & $\begin{array}{c}6.835^{* * * *} \\
(0.245)\end{array}$ \\
\hline Wlnhitechdens $_{\mathrm{gt}}$ & $\begin{array}{c}0.928^{* * * *} \\
(0.017)\end{array}$ & $\begin{array}{c}0.931^{* * * *} \\
(0.015)\end{array}$ & $\begin{array}{c}0.879^{* * * *} \\
(0.019)\end{array}$ & $\begin{array}{c}0.910^{* * * *} \\
(0.017)\end{array}$ & $\begin{array}{c}0.767^{* * * *} \\
(0.028)\end{array}$ & $\begin{array}{c}0.916^{* * * *} \\
(0.020)\end{array}$ & $\begin{array}{c}0.877^{* * * *} \\
(0.019)\end{array}$ & $\begin{array}{c}0.921^{* * * * *} \\
(0.016)\end{array}$ \\
\hline$\sigma_{\mathrm{e}}$ & $\begin{array}{c}1.474^{* * * *} \\
(0.038)\end{array}$ & $\begin{array}{c}1.553^{* * * *} \\
(0.041)\end{array}$ & $\begin{array}{c}1.523^{* * * *} \\
(0.040)\end{array}$ & $\begin{array}{c}1.617^{* * * *} \\
(0.044)\end{array}$ & $\begin{array}{c}1.630^{* * * *} \\
(0.057)\end{array}$ & $\begin{array}{c}1.969^{* * * *} \\
(0.071)\end{array}$ & $\begin{array}{c}1.531^{* * * *} \\
(0.040)\end{array}$ & $\begin{array}{c}1.583^{* * * *} \\
(0.042)\end{array}$ \\
\hline$\sigma_{\mathrm{u}}$ & & $\begin{array}{c}0.947^{* * * *} \\
(0.114)\end{array}$ & & $\begin{array}{c}0.984^{* * * *} \\
(0.134)\end{array}$ & & $\begin{array}{l}-0.292 \\
(0.254)\end{array}$ & & $\begin{array}{c}0.470^{* * * *} \\
(0.091)\end{array}$ \\
\hline constant & & $\begin{array}{c}13.454 \\
(12.266) \\
\end{array}$ & & $\begin{array}{c}25.383^{*} \\
(12.993) \\
\end{array}$ & & $\begin{array}{c}-11.987 \\
(19.081) \\
\end{array}$ & & $\begin{array}{r}12.275 \\
(9.875) \\
\end{array}$ \\
\hline \multicolumn{9}{|l|}{$\begin{array}{c}\text { Model } \\
\text { characteristics }\end{array}$} \\
\hline $\mathrm{N}$ & 830 & 830 & 830 & 830 & 498 & 498 & 830 & 830 \\
\hline $\mathrm{N}_{\mathrm{g}}$ & 83 & 83 & 83 & 83 & 83 & 83 & 83 & 83 \\
\hline log likehood & -1369.607 & -1629.726 & -1389.314 & -1660.625 & -796.757 & -1061.515 & -1392.913 & -1606.518 \\
\hline $\begin{array}{l}\text { Chi-square for } \\
\text { Wald's' test } \\
\text { on spatial lag }\end{array}$ & 3248.289 & 3768.778 & 2155.705 & 2800.360 & 777.883 & 2079.822 & 2124.416 & 3664.012 \\
\hline $\begin{array}{l}\text { P-value for } \\
\text { Wald's' test } \\
\text { on spatial lag }\end{array}$ & 0.000 & 0.000 & 0.000 & 0.000 & 0.000 & 0.000 & 0.000 & 0.000 \\
\hline aic & 2759.215 & 3283.451 & 2798.627 & 3345.249 & 1613.514 & 2147.031 & 2805.825 & 3237.035 \\
\hline bic & 2806.429 & 3340.108 & 2845.841 & 3401.906 & 1655.620 & 2197.558 & 2853.040 & 3293.693 \\
\hline FE & + & - & + & - & + & - & + & - \\
\hline $\mathrm{RE}$ & - & + & - & + & - & + & - & + \\
\hline
\end{tabular}

\section{Conclusions}

This paper extends the discussion regarding the significance of agglomeration externalities in the development of regional economies. The foundation of our debate is the 
concept of clustering and agglomeration economies that have been actively researched over the last 30 years in the academic literature (Porter, 1990; Becattini et al., 2003; Delgado et al., 2016). In our study, we examined the factors that stimulate the creation of the spillover effects in the hi-tech sector among Russian regions in the period ranging between 2008 and 2018. Results revealed two core findings. First, we discovered that the regions with a high density of the used high technologies tended to be located in close proximity. In general, they tended to collocate as either high-high or low-low. This trend could be explained by the unevenly developed infrastructure and the initial industrial foundation of certain regions. In other words, more developed regions in Russia have a higher density of the used high technologies than others and subsequently impact other more developed regions in the same manner, which demonstrates the agglomeration effect. Second, the concentration of high levels of employment, sales volume, and paid wages in the electrical equipment, electronic, and optical equipment sector revealed the positive association with hi-tech usage density. These externalities suggest the presence of positive direct or indirect spillover effects among the regions in Russia within the examined industry sector. This is consistent with the existing debate on the effects of agglomeration economies and their benefits (Feldman et al., 2005; de Groot et al., 2016). The result of such development is a loop in which the initial attraction of labor force, human resource management, and sales revenues attracts even more investors and prompts business activities. Moreover, a high level of employment, sales growth, and robust business practices further stimulate the development of the clustering process (Ketels, 2013; Delgado et al., 2014).

Our study uncovered a contradictory finding in which the concentration of investments did not display any positive association with hi-tech usage density. In the Russian case, it means that investments do not cause any direct or indirect spillover effects. As we have already mentioned, the hi-tech sector is essentially underfunded in Russia, as well as being negatively affected by cultural perceptions in terms of innovate entrepreneurship and business uncertainties. However, standard academic views suggest that investments, both from private and public institutions, are necessary for the development of any industry, especially for the stimulation of innovative activities (Iammarino and McCann, 2006; Ketels and Memedovic, 2008). The fundamentals of cluster implementation are competition and cooperation (Porter, 1990). If local or foreign private investors cannot provide the necessary funding for the region, the government has to assist with financial support (Vernay et al., 2018). Considering the realities of the Russian business world, the critical question remains: How to distribute necessary investments and funds to the regions so as to ensure their balanced development or so as to stimulate the effects of agglomeration externalities even in the remote areas of the country. The issue of uneven infrastructure foundations and severe disproportionate development of the regions remain relevant. Hence, recommendations for further research should involve the inclusion of more variables in statistical tests to conduct more sophisticated analysis of the hi-tech industry and its consequences and agglomeration effects. Calculations that include lag in their results would also be beneficial.

\section{Acknowledgements}

The reported study was funded by RFBR, project number 19-310-90069.

\section{References}

Aggarwal, A., 2011. Promoting Agglomeration Economies and Industrial Clustering Through SEZs: Evidence from India. Journal of International Commerce, Economics and Policy, Volume 2(2), pp. 201-227 
Becattini, G., Bellandi M., Ottati, G.D., Sforzi, F., 2003. From Industrial Districts to Local Development: An Itinerary of Research. Cheltenham: Edward Elgar Publishing Ltd.

Berawi, M.A., 2016. Value-based Innovation: Knowledge Technology Transfer in the Triple Helix Model. International Journal of Technology, Volume 7(1), pp. 1-4

Bessonova, E., Gonchar, K., 2017. Incentives to Innovate in Response to Competition: The Role of Agency Costs. Economic Systems, Volume 41(1), pp. 26-40

Brown, D., Earle, J., 2000. Market Competition and Firm Performance in Russia. Russian Economic Trends, Volume 9(1), pp. 13-18

Burawoy, M., 2001. Transition without Transformation: Russia's Involutionary Road to Capitalism. East European Politics and Societies, Volume 15(2), pp. 269-290

Bychkova, A., Rudskaia, I., 2018. Assessing the Efficiency of a Regional Innovation System as one of the Models for Running an Innovative Business. In: Proceedings of the 2018 International Conference on Internet and e-Business, pp. 208-212

Carpinetti, L.C.R., Lima, R.H.P., 2013. Institutions for Collaboration in Industrial Clusters: Proposal of a Per-Formance and Change Management Model. International Journal of Production Management and Engineering, Volume 1(1), pp. 13-26

Crescenzi, R., Jaax, A., 2017. Innovation in Russia: The Territorial Dimension. Economic Geography, Volume 93(1), pp. 66-88

de Groot, H.L.F., Poot, J., Smit, M.J., 2016. Which Agglomeration Externalities Matter Most and Why? Journal of Economic Surveys, Volume 30(4), pp. 756-782

Delgado, M., Porter, M., Stern, S., 2014. Clusters, Convergence, and Economic Performance. Research Policy, Volume 43(10), pp. 1785-1799

Delgado, M., Porter, M., Stern, S., 2016. Defining Clusters of Related Industries. Journal of Economic Geography, Volume 16(1), pp. 1-38

Elhorst, P.J., 2014. Spatial Econometrics: From Cross-Sectional Data to Spatial Panels. Berlin: Springer-Verlag Berlin Heidelberg

Enkel, E., Gassmann, O., Chesbrough, H., 2009. Open R\&D and Open Innovation: Exploring the Phenomenon. R\&D Management, Volume 39(4), pp. 311-316

Feldman, M., Francis, J., Bercovitz, J., 2005. Creating a Cluster While Building a Firm: Entrepreneurs and the Formation of Industrial Clusters. Regional Studies, Volume 39(1), pp. 129-141

Grigoriev, I.S., Dekalchuk, A.A., 2017. Collective Learning and Regime Dynamics under Uncertainty: Labour Reform and the Way to Autocracy in Russia. Democratization, Volume 24(3), pp. 481-497

Iammarino, S., McCann, P., 2006. The Structure and Evolution of Industrial Clusters: Transactions, Technology and Knowledge Spillovers. Research Policy, Volume 35(7), pp. 1018-1036

Ketels, C., 2013. Recent Research on Competitiveness and Clusters: What are the Implications for Regional Policy? Cambridge Journal of Regions, Economy and Society, Volume 6(2), pp. 269-284

Ketels, C., Memedovic, O., 2008. From Clusters to Cluster-based Economic Development. International Journal of Technological Learning, Innovation and Development, Volume 1(3), pp. 375-392

Kets de Vries, M., Shekshnia, S., Korotov, K., Florent-Treacy, E., 2004. The New Global Russian Business Leaders: Lessons from a Decade of Transition. European Management Journal, Volume 22(6), pp. 637-648

Klochikhin, E.A., 2012. Russia's Innovation Policy: Stubborn Path-Dependencies and New Approaches. Research Policy, Volume 41(9), pp. 1620-1630

Krugman, P.R., 1991. Geography and Trade. Cambridge, Massachusetts: MIT Press 
Kudryavtseva, T.J., Olaniyi, E.O., 2019. Identification and Analysis of the Cluster Structure of a Territory and its Impact on Regional Development: An example of Russia. Journal of Advanced Research in Law and Economics, Volume 10(4), pp. 1322-1337

Kudryavtseva, T., Skhvediani, A., Berawi, M.A., 2020. Modeling Cluster Development using Programming Methods: Case of Russian Arctic Regions. Journal of Entrepreneurship and Sustainability Issues, Volume 8(1), pp. 150-176

Kuznetsova, T., Roud, V., 2014. Competition, Innovation, and Strategy - Empirical Evidence from Russian Enterprises. Problems of Economic Transition, Volume 57(2), pp. 3-36

Lyapina, I., Mashegov, P., Petrukhina, E., Stroeva, O., Maltsev, A., 2019. Institutional Effects in Development of Regional Innovational Infrastructure. International Journal of Trade and Global Markets, Volume 12(1), pp. 26-42

Marshall, A., 2013. Principles of Economics. Palgrave Macmillan., Basingstoke

Moeis, A.O., Desriani, F., Destyanto, A.R., Zagloel, T.Y., Hidayatno, A., Sutrisno, A., 2020. Sustainability Assessment of the Tanjung Priok Port Cluster. International Journal of Technology, Volume 11(2), pp. 353-363

Moskovkin, V., Munenge, S., Mishunin, V., Sivakov, S., Ovchinnikova, O., 2016. Analysis of Regression Relationship between the Number of Organisations of the Russian Regional Innovation Infrastructure and the University Infrastructure and the Gross Regional Product. International Business Management, Volume 10(26), pp. 6026-6035

Nestle, V., Täube, F.A., Heidenreich, S., Bogers, M., 2019. Establishing Open Innovation Culture in Cluster Initiatives: The Role of Trust and Information Asymmetry. Technological Forecasting and Social Change, Volume 146, pp. 563-572

Newlands, D., 2003. Competition and Cooperation in Industrial Clusters: The Implications for Public Policy. European Planning Studies, Volume 11(5), pp. 521-532

Oglobina, S., Faria, A.P., Cabral-Cardoso, C., 2002. Research and Development in Russia and Its Role in National Competitiveness. International Journal of Innovation Management, Volume 06(02), pp. 131-161

Porter, M., 1990. The Competitive Advantage of Nations. New York: Free Press

Putri, E.P., Chetchotsak, D., Ruangchoenghum, P., Jani, M.A., Hastijanti, R., 2016. Performance Evaluation of Large and Medium Scale Manufacturing Industry Clusters in East Java Province, Indonesia. International Journal of Technology, Volume 7(7), pp. 1269-1279

Rodionov, D., Velichenkova, D., 2020. Relation between Russian Universities and Regional Innovation Development. Journal of Open Innovation: Technology, Market, and Complexity, Volume 6(4), pp. 1-26

Rodionova, I., Krejdenko, T., Mądry, C., 2018. Cluster Policy in the Russian Federation: A Case Study of Industrial Clusters. Quaestiones Geographicae, Volume 37(2), pp. 61-75

Ronen, S., Shenkar, O., 2013. Mapping World Cultures: Cluster Formation, Sources and Implications. Journal of International Business Studies, Volume 44(9), pp. 867-897

Sakwa, R., 2008. Russian Politics and Society (4th ed.). Oxon: Routledge

Samsonov, N. Yu., Tolstov, A. V., Pokhilenko, N. P., Krykov, V. A., Khalimova, S. R., 2017. Possibilities of Russian hi-tech rare earth products to meet industrial needs of BRICS countries. African Journal of Science, Technology, Innovation and Development, Volume 9(5), pp. 637-644

Serebryakova, N.A., Tolstykh, T.O., Dorokhova, N.V., Solomatina, E., Isaenko, M.I., 2018. The Effectiveness of using the Innovational Potential of a Socio-Economic System in Russia. International Journal of Trade and Global Markets, Volume 11(3), pp. 178-189

Sharafutdinova, G., Steinbuks, J., 2017. Governors matter. Economics of Transition and Institutional Change, Volume 25(3), pp. 471-493 
Sosnovskikh, S., 2017. Peculiarities in the Development of Special Economic Zones and Industrial Parks in Russia. European Journal of Geography, Volume 8(4), pp. 82-102

Tsukhlo, S.V., 2007. Competition in Russian Industry (1995-2002). Problems of Economic Transition, Volume 49(11), pp. 5-92

Vernay, A.-L., D'Ippolito, B., Pinkse, J., 2018. Can the Government Create a Vibrant Cluster? Understanding the Impact of Cluster Policy on the Development of a Cluster. Entrepreneurship \& Regional Development, Volume 30(7-8), pp. 901-919

Wiratmadja, I. I., Govindaraju, R., Handayani, D., 2016. Innovation and Productivity in Indonesian IT Cluster: The Influence of External Economies and Joint Action. International Journal of Technology, Volume 7(6), pp. 1097-1106

Xie, X. M., Wu, Y. H., Ma, G. X., 2016. Driving forces of industrial clusters towards innovative clusters: Accelerating the innovation process. Asian Journal of Technology Innovation, Volume 24(2), pp. 161-178 